\title{
Socialization of Da'wah through Technology Media Information with the Theme of Understanding Muslim Attitudes Facing the Covid-19 Pandemic Disaster
}

\author{
Irfan Santosa ${ }^{1)}$, Ghusni Darojatun ${ }^{2)}$ \\ ${ }^{1}$ Universitas Pancasakti Tegal, ${ }^{4}$ MTs Negeri Kota Tegal \\ Email: ci_ulya@yahoo.co.id*)
}

Received : 06 Auguts $2021 \quad$ Revised:09 Auguts $2021 \quad$ Accepted:09 Auguts $2021 \quad$ Publish:08 September 2021

\begin{abstract}
The covid-19 virus pandemic in Indonesia has been taking place since February 2020, which almost knocked out all sectors of the economy, industry, trade and human mentality. Data as of April 13, 2020 shows that the number of people in Indonesia contaminated with the covid-19 virus totals 4557 people, with the number of deaths of 399 people and patients cured reached 380 people (Source detik.com). From this data, the Government of Indonesia enacts and urges all people to stay at home or Stay at Home. With the program to stay at home, many people do all activities from home from work, study, worship done at home together with family. The implementation of staying at home from March 13, 2020 until now makes some people feel saturated, can't wait to stay at home so that many people are not disciplined in doing this program and still do regular activities in the midst of the covid-19 pandemic. The impact of impatience, indiscipline and disorderly behavior is what results in the number of contaminated sufferers every day is increasing.

Therefore, it is necessary to socialize about the understanding that should be done especially by every Muslim in the face of the covid-19 pandemic disaster. The method used is to make a video of da'wah containing a short message about patience in the face of disasters that last approximately 3 minutes and upload it online then share the online link through the group in Whatsapp group. The hope of this devotion program is that the community, especially Muslims, will be encouraged and self-conscious to be able to stay at home until the End of the covid-19 pandemic.

The results of this program after the video message was uploaded through Youtube then disseminated through Whatsapp group and watched approximately 150 times there are 25 people responded by sending a comment message to this video and 25 people will try to remain patient in the face of the test and implement government programs to stay home until the pandemic outbreak subsides.
\end{abstract}

Keywords: Da'wah, Information Technology Media, Muslim Attitude

\section{Introduction}

Education is basically a process of helping man in developing himself so that he can face all changes and problems with an open and creative attitude without losing his identity (Jawwas, 2017), as stated in the national education objectives formulated as follows: National Education aims to educate the nation's life and develop the whole Indonesian people, namely people who believe and fear God Almighty and have noble ethics have knowledge and skills, physical and spiritual health, a steady and independent 
personality and civic and national responsibilities (Suharto, 2017). In line with this goal, an educator should master the collection of knowledge, master the process, approach appropriate methods so as to support the target of our students to think critically, use reason effectively and instill the seeds of scientific attitudes and discipline, responsible transparency and confidence accompanied by faith and piety (Pratiwi, 2018). With these provisions, students are expected to have the ability to face the ever-changing future and become qualified human beings needed for the development of the nation. Therefore, a medium is needed as a means of liaison between educators and students (Basdogan et al., 2020).

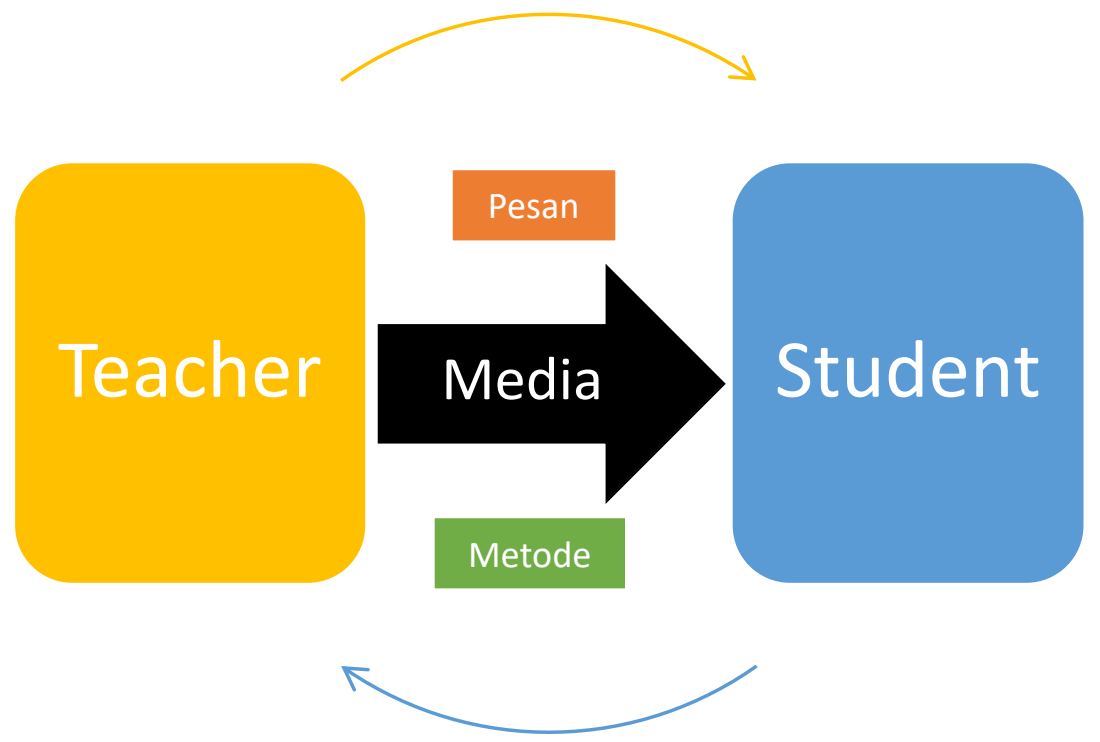

Figure 1. The relationship between messages and media

Several media benefits (Dominata \& Maharrani, 2020), namel the delivery of learning messages can be more standardized, learning can be more interesting, learning can be more interactive by applying learning theory, the implementation time of learning can be shortened, the quality of learning can be further improved. The type of media is divided into 3 large groups as depicted in the picture below (Suwana \& Lily, 2017): 


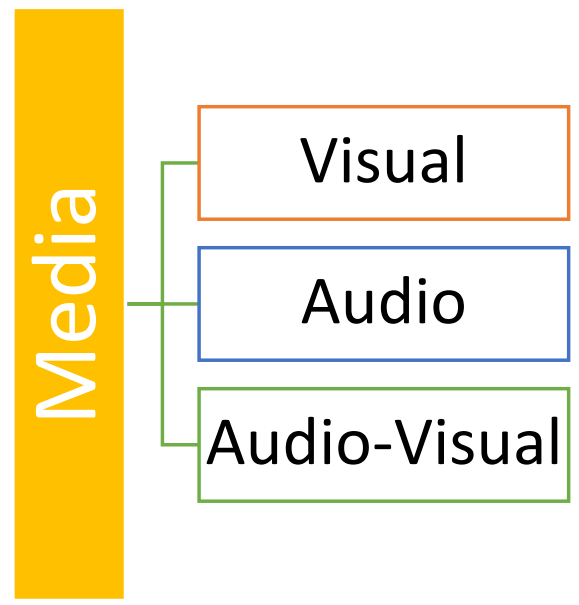

Figure 2. Classification of Learning Media

Visual Media is a visible medium, consisting of projected visual and non projected visual (Koltay, 2011). Audio media is a medium containing messages in the form of auditive (can only be heard) that can stimulate the mind, feelings, attention and willingness of the listener to learn the content of the theme. Audio-Visual media is a combination of visual media and audio media (Leaning, 2019).

Media is a method to convey to the audience about the theme of education to be delivered and is a systematic way and process that is done by an educator to achieve something (Wallis \& Buckingham, 2019). Methods are very important and no less important with the content. The use of media is an important sara to convey a message, especially to the community in the midst of a pandemic like this. The use of the internet as a medium of da'wah is one of innovation and opportunity as well as a challenge to expand the horizon of da'wah (Mardotillah et al., 2020).

The Covid19 virus pandemic in Indonesia has been taking place since February 2020, which almost knocked out all sectors of the economy, industry, trade and human mentality. Data as of April 13, 2020 shows that the number of people in Indonesia contaminated with the Covid19 virus totals 4557 people, with the number of deaths of 399 people and patients cured reached 380 people (Source: detik.com). From this data, the Government of Indonesia enacts and urges all people to stay at home or Stay at Home. 


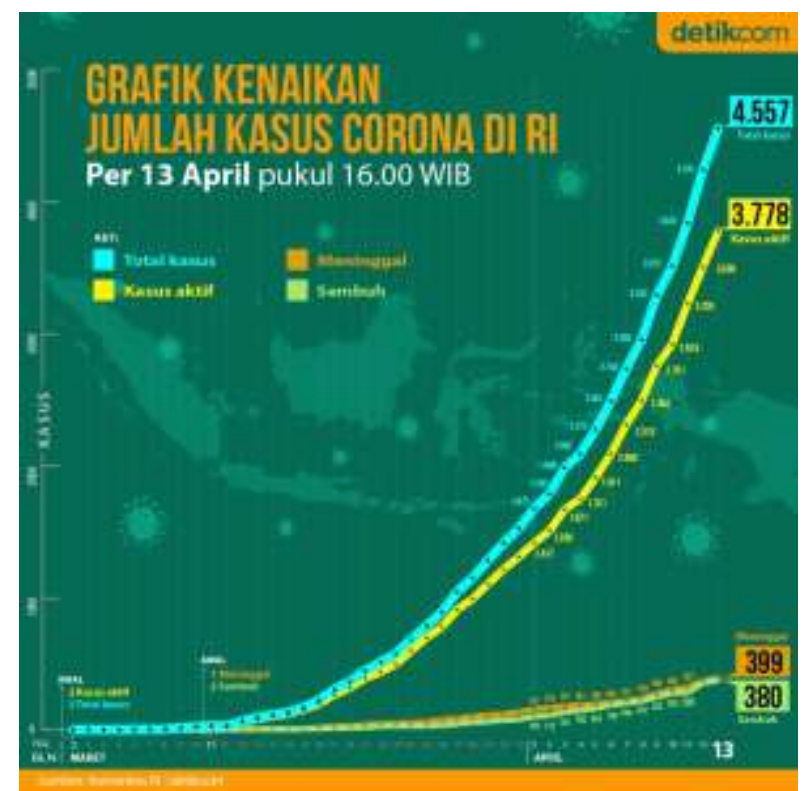

Figure 3. Graph of Corona case increase in The Republic of Indonesia as of April 13, 2020 (Source : https://news.detik.com/infografis/4975606/grafik-data-kasus-barucorona-per-hari-di-ri-data-2-maret-13-april-2020).

The implementation of staying at home from March 13, 2020 until now makes some people feel saturated, can't wait to stay at home so that many people are not disciplined in doing this program and still do regular activities in the midst of the Covid19 pandemic. The impact of impatience, indiscipline and disorderly behavior is what results in the number of contaminated sufferers every day is increasing.

Therefore, a solution is needed to realize to the public the importance of the implementation of staying at home either through electronic media or otherwise. So it encourages us as educators to create a message to the Muslim community in behaving to face the Covid19 pandemic.

\section{Method}

Methodology of the program Socialization of Da'wah Through Information Technology Media With the theme of Understanding Muslim Attitudes Facing the Covid19 Pandemic is to make a video of da'wah containing a short message with the theme of patience in the face of disasters that last approximately 3 minutes and upload it online then share the online link through Whatsapp group, the method of activity can be seen in the flow below: 


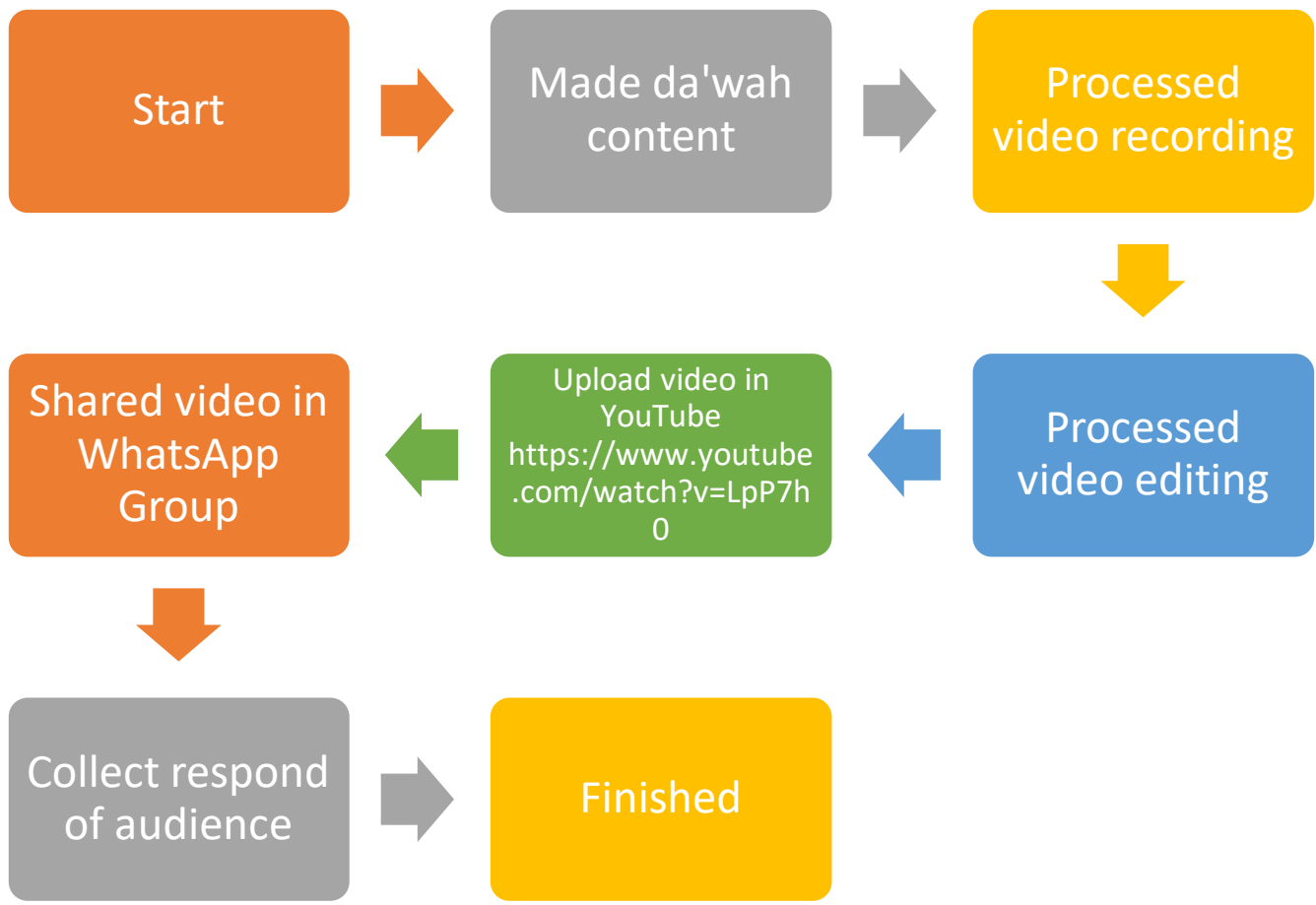

Figure 4. Flow chart of activities

\section{Result and Discussion}

\subsection{Result}

Socialization activities of Da'wah through Information Technology Media with the theme of Understanding Muslim Attitudes Facing the Covid19 Pandemic consists of several stages, among others: (a) Preparation Stage. At this stage is to make the design of the content / content of da'wah, the duration of da'wah, and the media that will be used so that it can be heard and conveyed well by the target / community. (b) Video Record Process. This process is to start recording using the Video Record facility on mobile phones, with a recording duration of 2 to 3 minutes. (c) Video Editing Process This step is to edit the recorded video file using the Video Editor application. The video editing process starts from the opening/initial design of the video, the content/content of da'wah and the cover. (d) Upload process on Youtube. At this stage after the video is declared finished the next edit is uploaded on yotube page using IKADI (Ikatan Da'I Indonesia) youtube channel in Tegal City. The link is as follows https://www.youtube.com/watch?v=LpP7h0NEY8c. (e) Video Publication. After the video is uploaded on Youtube page, the next step is to publish and socialize the video by sharing the video link and the link of the community's response to the video (whether 
content/ content, sound display, image display, and so on) through the existing Whatsapp Group.

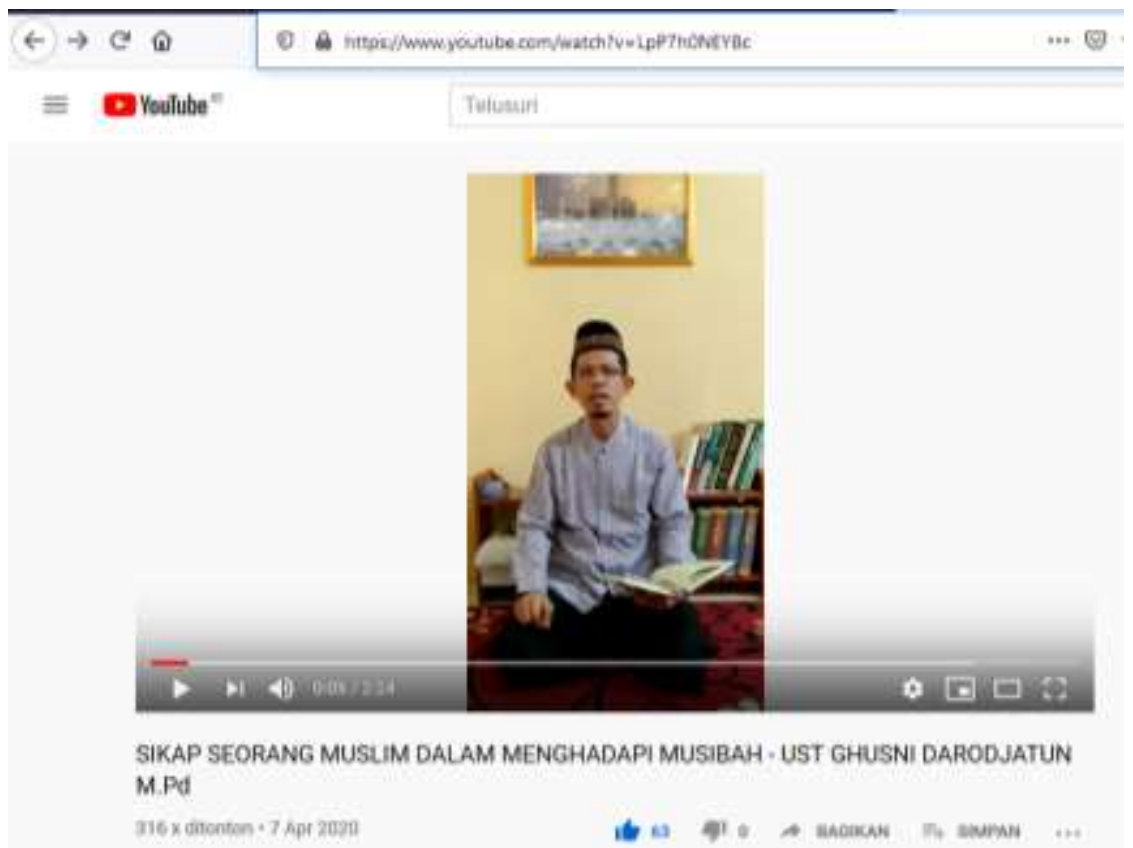

Figure 5. Video di Youtube (link https://www.youtube.com/watch?v=LpP7h0NEY8c.)

\subsection{Discussions}

Based on the video that has been uploaded on youtube page, that the link was watched 316 times with julah likes reached 63 and some viewers / audiences responded to comments. The results of the comment response are presented in the graphic picture below:

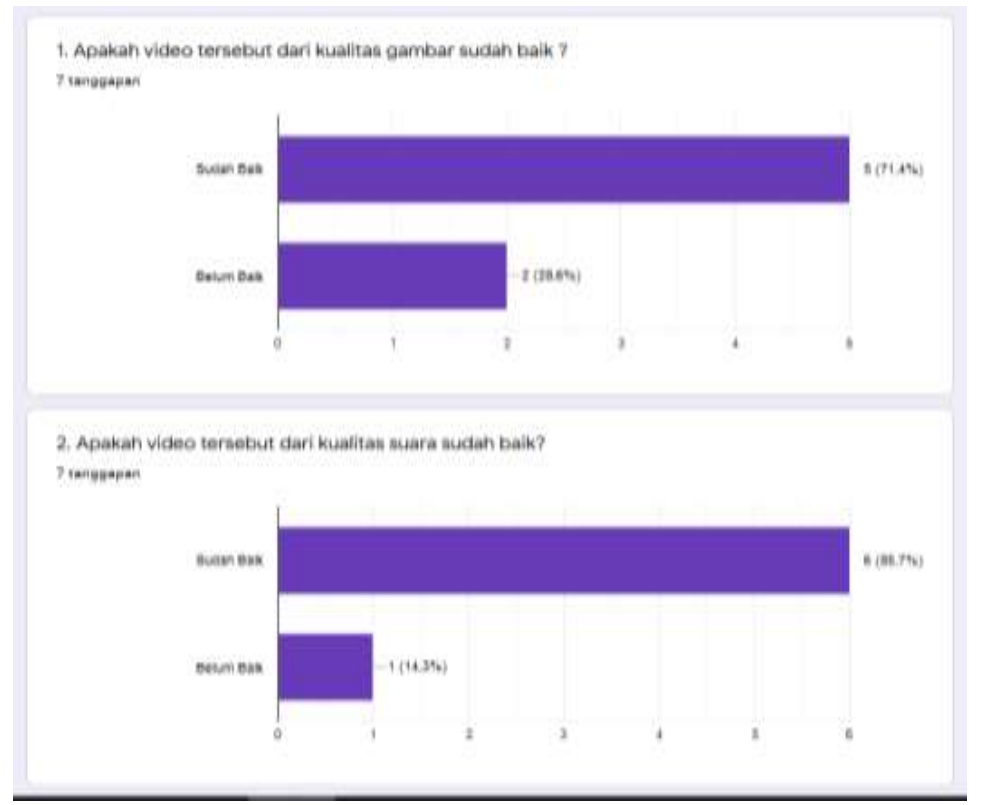

Figure 6. Community response to image and sound quality 
From figure 6 above, that the community response related to image/video quality has been good where the percentage reached $71.4 \%$ and only $28.6 \%$ answered less well in terms of video and sound quality. Then for the sound quality has also been very good with the number of respondents answering $85.7 \%$ and only $14.3 \%$ who answered less well in terms of sound quality.

3. Apakah isi/konten video tersebut sudah sangat jelas?

7 tanggapan

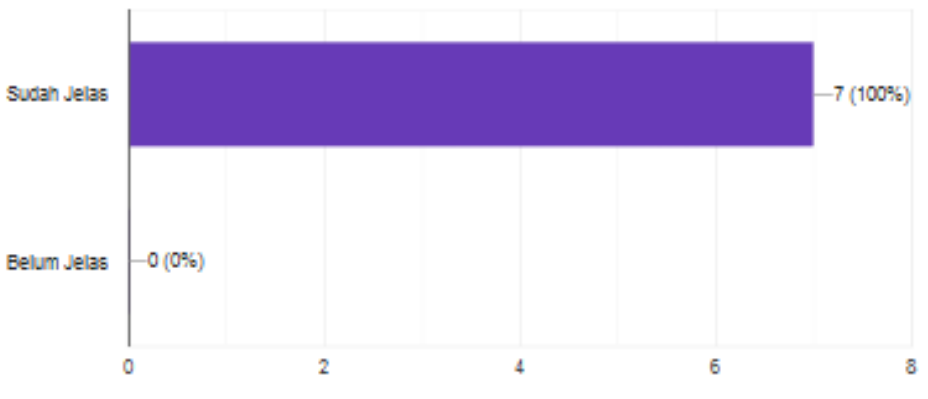

4. Apakah tema di dalam video tersebut sudah sesuai dengan kondisi saat ini?

7 tanggapan

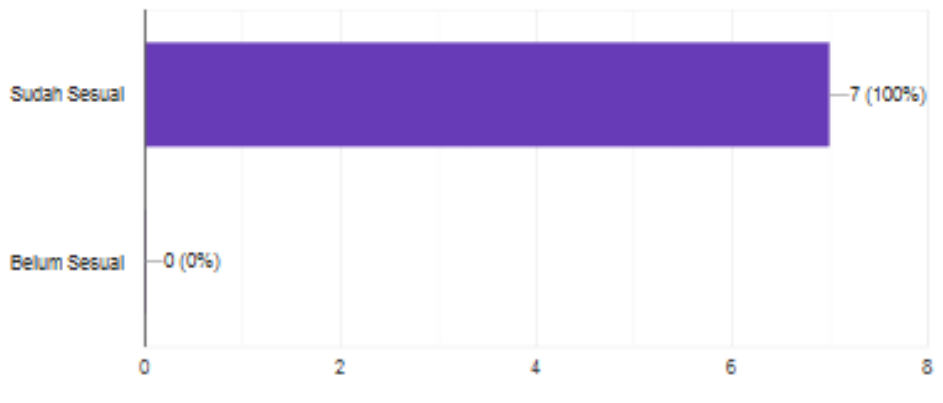

Figure 7. Community response to the content of da'wah and the suitability of the theme

From figure 7 above about the community response to the content of the video that respondents stated that it is in accordance with the percentage of answers $100 \%$. This proves that the content of the video is very appropriate to the current situation and conditions where we must be patient in dealing with the Covid19 pandemic disaster. 


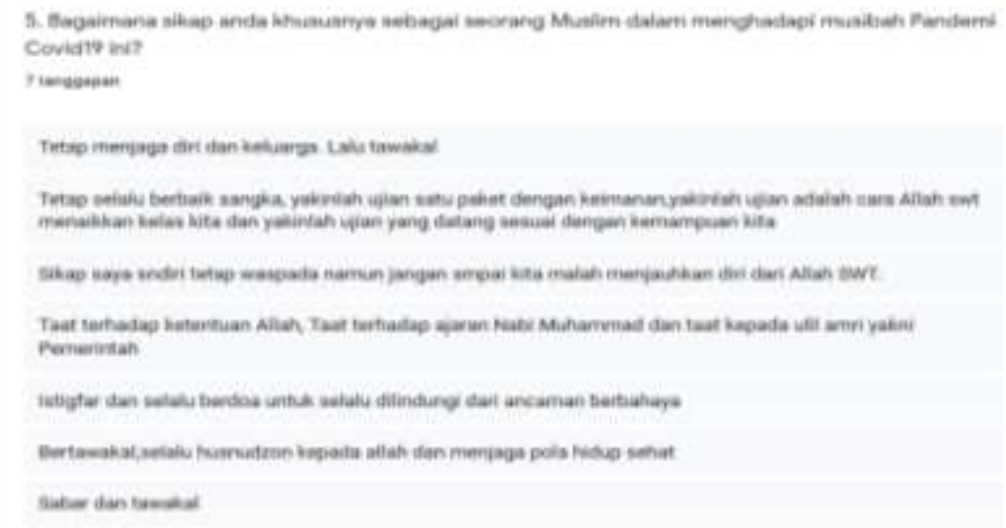

Figure 8. Community response after watching the video of da'wah

From figure 8 above is the result of feedback from respondents about the content of the da'wah that some respondents expressed their attitude as a Muslim in the face of the Covid19 pandemic disaster is to patiently accept the provisions of Allah the creator.

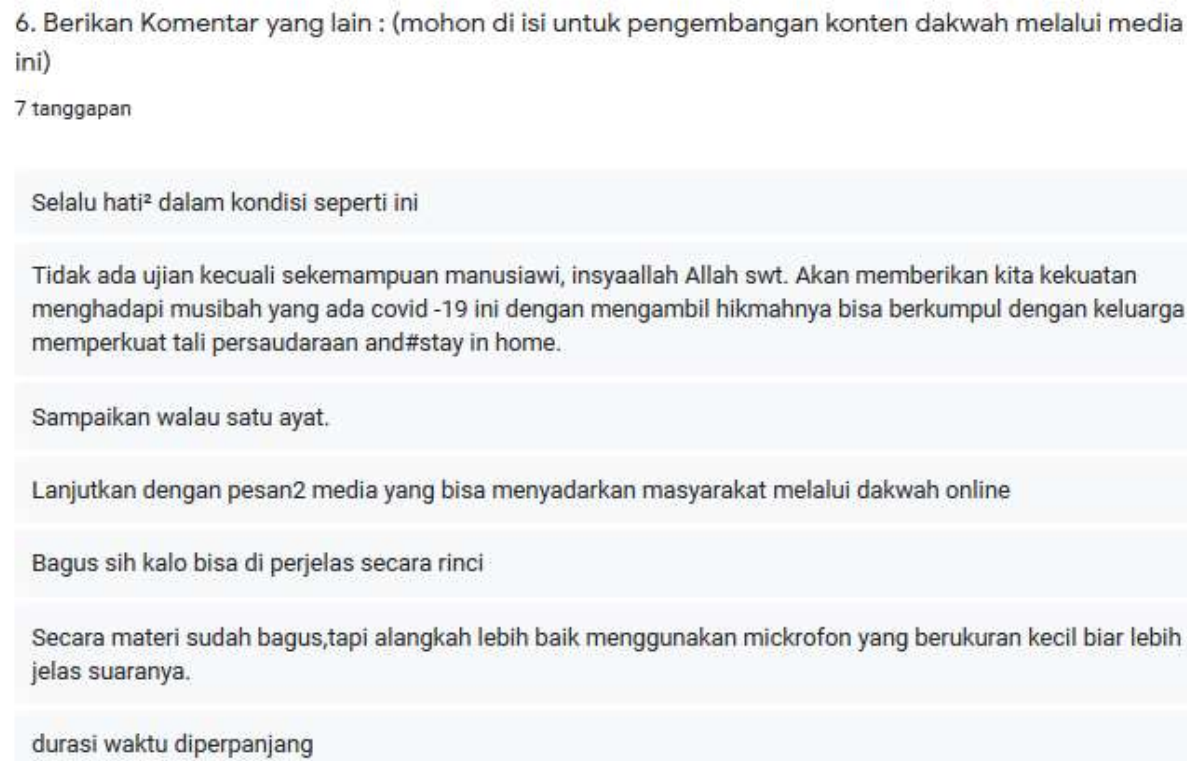

Figure 9. Community response to the development of da'wah content through online media

Based on the data above, the socialization of da'wah through information technology media with the theme of understanding Muslim attitudes facing the COVID19 pandemic disaster is very effective, because it was watched up to 316 times with the number of likes 63. Because if done using manual da'wah media (gathering people) with the number of up to 300 an is very difficult in addition to needing a place / location is 
quite wide and there are some things that must be prepared such as security, loudspeakers and so on that require a lot of costs.

\section{Conclusion}

Socialization of da'wah through information technology media with the theme of understanding muslim attitudes facing the Covid19 pandemic disaster is one type of community service conducted online considering there is a social or physical distance from the Government. But even though the limitations in the middle of this pandemic does not detract from our steps as educators to make a real contribution by realizing the understanding of the community in the face of disasters in the perspective of the Muslim community.

\section{Reference}

Basdogan, M., Ozdogan, Z., \& Bonk, C. J. (2020). Understanding the diverse field of "educational technology" as revealed in Twitter job postings: Encoding/decoding approach. The Qualitative Report, 25(8).

Dominata, A., \& Maharrani, D. (2020). Nine "smart policy solutions" to achieve green constitution and governance in Indonesia. International Journal of Advanced Science and Technology, 29(3 Special Issue).

Jawwas, F. A. (2017). METODE DAKWAH IMAM SHAFI'I DALAM ISTINBAT HUKUM ISLAM. Al-Mishbah / Jurnal Ilmu Dakwah Dan Komunikasi, 10(1). https://doi.org/10.24239/al-mishbah.vol10.iss1.39

Koltay, T. (2011). The media and the literacies: Media literacy, information literacy, digital literacy. Media, Culture and Society, 33(2). https://doi.org/10.1177/0163443710393382

Leaning, M. (2019). An approach to digital literacy through the integration of media and information literacy. Media and Communication, 7(2 Critical Perspectives). https://doi.org/10.17645/mac.v7i2.1931

Mardotillah, M., Hendro, A., Soemarwoto, R., \& Raksanagara, A. (2020). Peran Masjid Lautze 2 Bandung dalam Dakwah dan Budaya. Khazanah Theologia, 2(1). https://doi.org/10.15575/kt.v2i1.8188

Pratiwi, A. F. (2018). FILM SEBAGAI MEDIA DAKWAH ISLAM. Aqlam: Journal of Islam and Plurality, 2(2). https://doi.org/10.30984/ajip.v2i2.523

Suharto, S. (2017). EFEKTIVITAS KOMUNIKASI DAKWAH: KECERDASAN KOMUNIKASI DAN RETORIKA DAKWAH. Al-Mishbah / Jurnal Ilmu Dakwah Dan Komunikasi, 10(1). https://doi.org/10.24239/al-mishbah.vol10.iss1.35

Suwana, F., \& Lily. (2017). Empowering Indonesian women through building digital media literacy. Kasetsart Journal of Social Sciences, 38(3). https://doi.org/10.1016/j.kjss.2016.10.004

Wallis, R., \& Buckingham, D. (2019). Media literacy: the UK's undead cultural policy. International Journal of Cultural Policy, 25(2). https://doi.org/10.1080/10286632.2016.1229314 